Available online on 15.02.2020 at http://jddtonline.info
Open Access to Pharmaceutical and Medical Research
unrestricted non-commercial use, provided the original work is properly cited

Open $\odot$ Access

Review Article

\title{
Role of Dietotherapy in Lifestyle disorders: An overview
}

\author{
Amreen Zehra $^{1 *}$, Abdul Mannan' ${ }^{2}$ Mursaleen Naseer ${ }^{3}$, Maryam Zafar' ${ }^{1}$, Yasra Farooqui ${ }^{1}$ \\ 1-PG Scholars, Department of Moalejat, AKTC, AMU, Aligarh \\ 2- Professor, Department of Moalejat, AKTC, AMU, Aligarh \\ 3- Assistant Professor, Department of Moalejat, AKTC, AMU, Aligarh
}

\begin{abstract}
Objective: The aim of the present study to evaluate the role of dietotherapy in lifestyle disorders.

Background: The incidence of lifestyle disorders like hypertension, diabetes mellitus, dyslipidemia, and obesity associated with cardiovascular diseases is high on the rise. Cardiovascular disorders continue to be the major cause of mortality, representing about $30 \%$ of all death worlds wide. In the Unani System of Medicine (USM) of lifestyle, the disorder is the diseases that arise from the imbalance in asbabe- sitta-zarooriya over a long period.

The management of the diseases in USM is largely based on the holistic approach. Four modes of treatment are employed, such as regimental therapy, dietotherapy, pharmacotherapy, and surgery. The dietotherapy is one of the most important non-medical therapy in which treatment is done through modulation in dietary habit which is necessary for the prevention and control of diseases. The principle aim of dietotherapy is to maintain nutritional needs according to the demand of the body and avoid drugs as it is not considered to be part of the body and produce adverse reactions.
\end{abstract}

Conclusion: The rationale for dietotherapy is that lifestyle disorder brought about by a faulty diet can be reversed or reduced by change s to this diet. Dietotherapy involves recommending a specific diet which is the simplest and most natural course of treatment by USM.

Keywords: Lifestyle disorders, dietotherapy, diabetes mellitus, hypertension, obesity, unani system of medicine (USM)

Article Info: Received 22 Nov 2019; Review Completed 20 Jan 2020; Accepted 27 Jan 2020; Available online 15 Feb 2020

Cite this article as:

Zehra A, Mannan A, Naseer M, Zafar M, Farooqui Y, Role of Dietotherapy in Lifestyle disorders: An overview, Journal of Drug Delivery and Therapeutics. 2020; 10(1-s):208-210 http://dx.doi.org/10.22270/jddt.v10i1-s.3909

*Address for Correspondence:

Amreen Zehra, PG Scholars, Department of Moalejat, AKTC, AMU, Aligarh

\section{Introduction:}

Lifestyle diseases are defined as diseases linked with the way people live their life. This is commonly caused by alcohol, drugs, and smoking abuse as well as lack of physical activity and unhealthy eating. ${ }^{1}$

The incidence of lifestyle disorders like hypertension, diabetes mellitus, dyslipidemia, and obesity-associated with cardiovascular diseases is high on the rise. Cardiovascular disorders continue to be the major cause of mortality representing about $30 \%$ of all death worlds wide.

With rapid economic development and increasing westernization of lifestyle in the past few decades prevalence of these diseases has reached alarming proportion among Indians in recent years. ${ }^{2}$
A good diet or adequate diet is known as balanced $\operatorname{diet}^{3} \mathrm{~A}$ well-balanced diet with adequate intake of all nutrients is necessary for food nutrition.

The USM based on the concept of asbabe sitta zarooriya, which includes hawae muheet, makoolat wa mashroobat, harkat wa sukoon-e-badni, harkat wa sukoon-e-nafsani, naumwa-yaqza and ehtebas -wa-istafragh. In Unani System of Medicine (USM) of life style disorder are the diseases which arise from the imbalance in asbabe-sitta-zarooriya over a long period. The management of the diseases in USM is largely based on holistic approach. Four modes of treatment is usually employed, such as regimental therapy, dietotherapy, pharmacotherapy, and surgery. The dietotherapy is one of most important non-medical therapy in which treatment is done through by modulation in dietary habits which is necessary for prevention and control of diseases ${ }^{4}$ 
In practice, dietotherapy involves encouraging a person with a chronic disorder, brought on by a faulty or imprudent personal lifestyle, to consciously adopt reasonable and realistic changes to his or her diet, to reverse the Physis is the body's intrinsic ability to heal itself from within, without outside help. It is our 'inner doctor' progress of the disorder. In Tibb, such dietary changes aim to restore equilibrium or harmony to the qualities involved in the person's temperament. Dietotherapy is a major therapeutic option, along with cupping, herbal medication (or phytotherapy), and massage. As with all forms of treatment in Tibb, it respects Physis, the body's innate capacity for self-healing: "the doctor within us all." It is an approach to health maintenance and disease alleviation, which is completely safe, and, if carried out properly, free from any adverse consequences. By supporting and enhancing Physis, it restores the person's intrinsic harmony between the qualities.

In most cases, the actual type of food or its nutritive value is not important; it is its ability to reverse the disordered qualities that have lead insidiously to the chronic ailment in the first place. The consumption of specific foods is encouraged, and the omission of deleterious foods discouraged. 13

\section{Quotes Regarding Diets:}

Hippocrates quoted that "The cause of sickness is overeating and the cause of health is eating like a bird."

Ibne Sina quoted that "Stomach is the house of diseases and the diet is the head of healing."

\section{Application of Dietotherapy in the following diseases}

\section{Obesity (Siman mufrit)}

\section{Principle of diet}

- Low-calorie diet

- $\quad$ Normal protein, vitamins, and minerals (except $\mathrm{Na}$ )

- $\quad$ High fibrous $\operatorname{diet}^{5}$

According to Buqrat (Hippocrates), the quality (kaifiyat) and quantity (kammiyat) of diet and the importance of a balanced diet concerning the occurrence of the disease are important factors in the treatment of obesity.

- $\quad$ Reduce the amount of food.

- $\quad$ Avoid all rhoghni ghizayein (fatty diet).

- To Promotes fasting in obese people.

- $\quad$ Restrict meat, milk, and liquor.

- $\quad$ Eat vegetables in excess.

- Hot spices should be added in ghiza e.g filfildaraz, zeera, lehsun because they have mulattif properties.

- $\quad$ Food should be cooked in vinegar. ${ }^{6}$

\section{Diabetes mellitus (ziyabetes shakri)}

Achieving energy balance and maintaining healthy body weight is critical for the prevention and treatment of type 2 diabetes, and limiting saturated fat intake can help prevent the vascular complications of diabetes. Higher consumption of whole grain and dietary fibers associated with reduced risks of diabetes in some studies.7
- $\quad$ Frequently but low amount of food should be eaten throughout a day. Excessive at sometime and longer fasting should be avoided.

\section{General consensus on proportion of food constituents is} as follows

- $45-65 \%$ of total carbohydrate (complex form will have more fiber)

- $\quad 10-30 \%$ as protein,

- $\quad<30 \%$ of total fat or $<7 \%$ saturated fat ${ }^{8}$

Non -nutritive sweetners, e.g., sachcharin, aspartum can be used in moderation. 8

\section{Food to be avoided}

- Simple sugar, glucose, syrup, sweets, alcohol, nuts, refined flour, etc.

The cornerstone for the success of overall glycemic control-

Diet plan should be flexible, reflecting patient's lifestyle, work schedule, and local meal preparation. ${ }^{8}$

\section{Hypertension (zightamdum qawi)}

Appropriate lifestyle measure may obviate the need for drug therapy in patients with borderline hypertension, reduce the dose or the number of drugs required in patients with established hypertension, and directly reduce cardiovascular risk. ${ }^{12}$

Dietary salt reduction- $<6 \mathrm{~g}$ NACL/day

Adopt DASH type dietary plan - a diet rich in fruits, vegetables, and low-fat dairy products with reduced content of saturated and total fat. 9

Adequate nutritional intake of minerals ${ }^{11}$

For therapeutic purpose taqleele ghiza (i.e. either reducing the quantity of diet or increasing the bulk of food but not qualities like vegetable and fruits) ghiza mulattiff (dietary items which produces lateef khoon e.g honey, injeer etc this type of diet help in thining of blood as the thick and viscous matter get to adhere to the vessel wall and become a reason for raised blood pressure). ${ }^{10}$

\section{Conclusion}

The rationale for dietotherapy is that lifestyle disorder brought about by a faulty diet can be reversed or reduced by changes to this diet. A dietotherapy plays a vital role in the prevention and treatment of several body ailments. This form of treatment is widely acceptable, accessible, and above all, affordable to the patient with very little adverse effects. In the present scenario, several lifestyle disorders such as hypertension, diabetes mellitus, dyslipidemia etc managed by selecting an appropriate diet either alone or as adjuvant with pharmacotherapy. Despite its importance, there is a lack of uniform standards for its application in clinical use. Therefore it is high time that this age-old therapy needs further clinical trial for scientific validation for wider acceptability so that humankind may gain its wonderful benefits.

\section{References}

1-en.wikipedia.org/wiki/Lifestyle_disease

2- Pappanchan MJ. Increasing prevalence of lifestyle diseases: high time for action. Indian J Med Res. 2011; 134:143-5

3-Onila salins, Essence of nutrition: page no-57 
4-.Ansari Parvez Athar Rizvi, N Zaheer Ahmad, Abdul Wadud- Ilaj bil ghiza (dietotherapy): A core modes unani treatment, journal of advanced research in pharmaceutical sciences and pharmacological intervention volume 2, issue 1-2018 page no27-35)

5-BD khan, Mohammed Mohsin, dietotherapy

6-Mubarak Ali, Sofia Naushin, concept of obesity and its unani managements-A review, European journal of pharmaceutical and medical research.

7-Manztzoros Christos S MD, DSc- Obesity and Diabetes page no. 447

8-Ahuja MMS, Diabetes care in clinical practice page no-15

9-Kasper, Fauci, Haucer, longo, Jamson,Loscalzo, Harrison's principle of internal medicine $19^{\text {th }}$ edition page no-
10-Parveen Aliya,Mohd Saqlain, Zarnigar, unani medicine -A guiding tool for the management and control of Hypertension, world journal of pharmaceutical research vol 4 issue 11 review article

11- Pavan Bhat MD, Alexendra Dretler MD, Mark Gowski, MD, Rajeev Ramgopal,Dominique Williams MD .The southeast edition of Washington manual of medical therapeutics $.35^{\text {th }}$ edition page 61

12- Brian R Walker, Nicki R Colledge, Stuart H.Ralston and Ian D.penman. Davidson's Principle and practice of medicine $.22^{\text {nd }}$ edition page -673 .

13-Dr. John Glynn, Mrs Nasira Bhikha-Vallee and Prof Rashid Bhikha-Dietotherapy: Background and theory, Tibb institute -A science of medicine the art of core july 2013 